\title{
THE JAPAN -US MILITARY ALLIANCE AND THE ASIA-PACIFIC CHALLENGES: PROSPECTS FOR DEEP CHANGES
}

\author{
Antonio Marquina ${ }^{1}$ \\ UNISCI Director
}

\begin{abstract}
:
In the last fifteen years a fundamental shift in the strategic balance in Asia - Pacific has taking place. The article aims at discussing the difficulties the Japan-US military Alliance has adaptating to this new regional strategic environment. It also explains the new strategy that President Obama's Administration is trying to implement, initially called "Pivot to Asia" and later "Rebalance". The article tries to show the challenges that this new strategy implies for both Japan and the United States, enumerating different scenarios some of them not very likely and highlighting on the contrary the possibility of a more assertive and military independent Japan.
\end{abstract}

Keywords: Japan, United States, China, Russia, pivot to Asia, Rebalance, Asia-Pacific, Armed Forces, Defense Strategic Guidance, Air-Sea Battle, Joint Operational Access Concept, Anti-Access and Anti-Area Aenial, Pacific Century, Nuclear Modernization.

\section{Resumen:}

En los últimos quince años se ha producido un cambio fundamental en el equilibrio estratégico de Asia-Pacífico. El artículo trata de presentar las dificultades de adaptación de la alianza de Japón con Estados Unidos al nuevo contexto estratégico. Asimismo presenta la nueva estrategia que está tratando de implementar la administración del presidente Obama denominada inicialmente "pivot to Asia" y posteriormente "rebalance". El artículo trata de mostrar los desafíos que esta nueva estrategia tiene para Japón y los Estados Unidos, presentado varios escenarios cuya probabilidad es cuestionable, y decantándose por una mayor reafirmación de Japón.

Palabras clave: Japón, Estados Unidos, China, Rusia, "pivot to Asia”, re-equilibrio, fuerzas armadas de AsiaPacífico, "Defense Strategic Guidance”, Guerra aire-tierra, "Joint Operational Access Concept", "anti-access and anti-area Denial, el siglo del Pacífico, modernización nuclear.

Copyright () UNISCI, 2013.

Las opiniones expresadas en estos artículos son propias de sus autores, y no reflejan necesariamente la opinión de UNISCI. The views expressed in these articles are those of the authors, and do not necessarily reflect the views of UNISCI.

\footnotetext{
${ }^{1}$ Antonio Marquina Barrio is Chair on Security and Cooperation in International Relations, Director of the Department of Public International Law and International Studies of the Universidad Complutense de Madrid (UCM), Director of UNISCI . His main research lines are security in Europe, the Mediterranean, Asia-Pacific, arms control and soft security issues.

Address: Departamento de Estudios Internacionales, Facultad de Ciencias Políticas y Sociología, UCM, Campus de Somosaguas, 28223 Madrid, España.

E-mail: marioant@cps.ucm.es.
} 


\section{Introduction}

Japan is in a process of redefining its position in the international arena. This factor has a critical impact on its security and defense policy and carries important consequences for its traditional relations with the United States, while it also affects its international economic policy. The new LDP government is attempting to revitalize the economy after a very weak performance in recent years and is avoiding at the same time a strong degree of dependence on Chinese economic policies. This government is also wary of any possible economic integration of Asia- Pacific under Chinese aegis.

At the same time, Japan's relations with the United States are influenced by a broader context determined by U.S. policies toward Asia-Pacific as well as all changes that the U.S. has undertaken in recent years.

In the international relations literature, the claim that Asia-Pacific was not a priority in the United States security policies after the end of the Cold War is very recurrent. In fact, still in the nineties these policies were essentially focused on Central and Eastern Europe and eventually, on the Middle East. Although the first George W. Bush Administration initially intended to focus on Asia-Pacific, it was the Middle East and Afghanistan which at the end ended up occupying a central stage in his security and defense policy.

In this respect, this article deals with several significant changes in the U.S. policies toward the region as well as in the US- Japan military Alliance and leaves open many questions on the possible evolution of the US- Japan bilateral relations.

\section{President Obama Administration and Asia-Pacific}

\section{Strategic Reassurance}

The first Obama Administration initially emphasized the importance of the Asia-Pacific in its foreign and security policies and coined thus the concept of Strategic Reassurance to capture the security relations between United States and China, ranked as a priority issue. On the other hand, with the victory of the Democratic Party of Japan (DPJ) on the $16^{\text {th }}$ September 2009 and the rise to power of Yukio Hatoyama, there were many signs pointing to Japan seeking to develop a foreign policy more independent of the United States.

With respect to China, James Steinberg, Deputy Secretary of State stated in a speech at the Center for the New American Security on 24 September 2009 that: "China must reassure the rest of the world that its development and growing global role will not come at the expense of security and well-being of others. Bolstering that bargain must be a priority in the U.S.-China relationship. And strategic reassurance must find ways to highlight and reinforce the areas of common interest, while addressing the sources of mistrust directly, whether they be political, military or economic" ${ }^{2}$.

\footnotetext{
${ }^{2}$ Steinberg, James B.: "China's Arrival: The Long March to Global Power", Keynote Address by U.S. Deputy Secretary of State, Transcript of Records, Center for a New American Security (CNAS) (24 September 2009), at http://www.cnas.org/files/multimedia/documents/Deputy\%20Secretary\%20James\%20Steinberg\%27s\%20Septe mber\%2024,\%202009\%20Keynote\%20Address\%20Transcript.pdf.
} 
These approaches, which echoed some of those by Banning Garrett, ${ }^{3}$ became the object of intense criticism. Republican and conservative groups expressed a deep skepticism on this approach that "naively assumed that China's leadership does not see the world in terms of power politics" and which changes the former US concept demanding China to be a "responsible stakeholder" in the international system. ${ }^{4}$ On the contrary according to the State Department the new policy was actually toughened of the Bush Administration concept of "responsible stakeholder" as it focused on what China needed to do for reassuring the United States and the world. ${ }^{5}$

In fact, the concept barely accomplished anything. China became more assertive, clashing at sea with Japan, Vietnam and the Philippines, and refusing to pressure the government of the Democratic People's Republic of Korea after its military aggressions to the Republic of Korea; while the US tried to maintain some level of neutrality in regards to territorial issues and made tactful responses to various Chinese initiatives seeking to take advantage of its economic power and obtain diplomatic and security dividends in the region, ${ }^{6}$ China did not deliver accordingly, dashing thus US expectations created with the new concept of strategic reassurance. A partnership with China appeared to be a complicated task indeed.

Shortly afterwards we would assist to the launching of another concept: "The US pivot in Asia", which broadened the former concept. Hillary Clinton in a speech at the East West Center in Honolulu on 10 November 2011 entitled America's Pacific Century, launched and explained the concept. ${ }^{7}$

\footnotetext{
3 "Strategic reassurance measures" (SRMs) seek to address the deeper causes of mistrust among nations, especially suspicions about the perceived long-term political, military, and economic objectives-that is, strategic intentions-of other powers": Garrett, Banning: "The Need For Strategic Reassurance in the 21st Century", Arms Control Today, March 2001, at http://www.armscontrol.org/print/810.

4 See for instance: Strategic reassurance is "a narrow formula for managing the increasing propensity for the U.S. and China to rub up against each other in security matters, such as U.S. naval operations that fall within what China claims is its exclusive economic zone, or as a mechanism for calming Chinese fears about the security of their large pile of dollar-denominated assets. But there is also a more damaging interpretation, given the administration's downplaying of human rights on the bilateral agenda, the decision not to meet with the Dalai Lama during his recent visit to Washington, and the endless chase for Chinese cooperation on a raft of other "important" issues from climate change to Iran. What if "strategic reassurance" is nothing more than a fancy way of saying "appeasement"?": Currie, Kelley: "The Doctrine of 'Strategic Reassurance' What does the Obama formula for U.S.-China relations really mean?”, Wall Street Journal, 22 October 2009, at http://online.wsj.com/article/SB10001424052748704224004574488292885761628.html; Lee, Peter: "The New Face of U.S.-China Relations: "Strategic Reassurance” or Old-Fashioned Rollback?", The Asia-Pacific Journal (19 July 2010), at http://www.japanfocus.org/-peter-lee/3385; Osmos, Evan: Strategic Reassurance, The New Yorker, 6 October 2009; Kagan, Robert and Blumenthal, Dan: "Strategic Reassurance that isn't", Washington Post, 10 November 2009.

${ }^{5}$ Kagan, Robert:" The meaning of "strategic reassurance", The Washington Post, 11 November 2009.

${ }^{6}$ Lieberthal, Kenneth G.: The American Pivot to Asia, Brookings Foundation (21 December 2011) at, http://www.brookings.edu/research/articles/2011/12/21-obama-asia-lieberthal.

${ }^{7}$ Some of the main ideas were the following: In the $21^{\text {st }}$ century the world's strategic and economic center of gravity will be located in Asia and the same way the US played a central role in shaping the economic and security architecture across the Atlantic during the Cold War, they will try to do the same across the Pacific. The $21^{\text {st }}$ century will be the America's Pacific Century. What happen's in Asia in the years ahead will have an enormous impact on our nation's future and we cannot afford to sit on the sidelines and leave it to others to determine our future. There are challenges facing the Asia-Pacific right now that demand America's leadership. The United States has unique capacities to bring to bear in these efforts and strong national interest at stake. Now that's the why of America's pivot towards the Asia Pacific.
} 
Hillary Clinton presented six key lines of action, one of which was "strengthening our bilateral security alliances"

This announcement was made just when President Obama was starting his third trip to visit Asia. In Australia, in his remarks to the Australian Parliament on 17 of November, President Obama emphasized that the US was a Pacific power, eager to help laying the ground for economic success, ready to stay in the region, maintaining a strong military presence, enhancing its presence across Southeast Asia and helping both allies and partners to build-up their military capacities. The US-Japan alliance was to be the cornerstone of regional security, while a cooperative relationship with China should nevertheless be maintained. ${ }^{9}$ The US commitment to Asia and the Pacific was made clear and it was to be perceived as such, as the US wanted to secure a strong position in the region.

The US announcement of a new "pivot to Asia" strategy that rather than a transformation represented an enhancement of previous ones ${ }^{10}$, arouse suspicion and drew widespread criticism in China. Statements and briefings by Pentagon officials on the Air-Sea Battle concept to be implemented ${ }^{11}$ and official US documents published by the Pentagon, such as Defense Strategic Guidance ${ }^{12}$, only reinforced this perception. ${ }^{13}$ The US shift from land wars to the "Air-Sea Battle" bad sign for China. The provision for capabilities to enable operational access in anti-access and area-denial environments was especially important in the Pacific where China was developing exactly the capabilities to deny the US entry in areas of special strategic importance to China such as the first island chain. Although at the official level the explanation was that the concept was not exclusively focused on China, the fact is that articles and explanations mostly ended up focusing on China, even detailing the battle plan to thwart any anti-access and anti-area denial strategies. The context in which the different documents and concepts were launched was crystal clear: China's economic and military modernization was de facto changing the regional status quo. The United States did not want to allow China either alone or in tandem with other Asian countries shape the Asia- Pacific according to its own interests. From this perspective, the concept had a strong economic and diplomatic component.

The implications were important. The Chinese perception that the US pretended to divide and rule, separating China from its neighbors and contain China implied that dialogue

\footnotetext{
${ }^{8}$ The six key lines were the following: strengthening our bilateral security alliances; deepening our working relationships with emerging powers; engaging with regional multilateral institutions; expanding trade and investment; forging a broad-based military presence; and advancing democracy and human rights.

9"Remarks by President Obama to the Australian Parliament", 17 November 2011, at http://www.whitehouse.gov/the-press-office/2011/11/17/remarks-president-obama-australian-parliament.

${ }^{10}$ Marlin Mark E. (coord): "Pivot to the Pacific? The Obama Administration's "Rebalancing" towards Asia", CRS, (28 March 2012), p.2, at http://www.fas.org/sgp/crs/natsec/R42448.pdf.

${ }^{11}$ US Department of Defense (DoD): "Background Briefing on Air-Sea Battle by Defense Officials from the Pentagon", 9 November 2011, at http://www.defense.gov/transcripts/transcript.aspx?transcriptid=4923.

12 US Department of Defense (DoD): "Sustaining U.S.Global Leadership: Priorities for the 21 st Century Defense" (January 2012), at http://www.defense.gov/news/defense strategic guidance.pdf.

${ }^{13}$ Weliz, Richard: "Asia Overreacts to US Military Pivot", The Diplomat, 25 January 2012, at http://thediplomat.com/2012/01/25/asia-overreacts-to-u-s-military-pivot/; A good example of the Chinese perception is: Feng, Zhu:' Obama's "Pivot to Asia" Strategy and Sino-US Relations', China Institutes of Contemporary International Relations (CICIR), at http://www.cicir.ac.cn/english/ArticleView.aspx?nid=4087.

${ }^{14}$ The concept of Air-Sea Battle was announced in the Quadrennial Defense Review of 2010.

${ }^{15}$ US Department of Defense (DoD): "Joint Operational Concept" (17 January 2012), at http://www.defense.gov/pubs/pdfs/joac_jan\%202012_signed.pdf.
} 
and cooperation with China in critical global and regional issues would become much more difficult. This would necessarily exacerbate tensions with China.

But this new orientation had crucial implications for the allies of the United States in the region too. They feared that all this would imply greater expenditures and greater military budgets and the potential loss of significant profits obtained in economic and financial relations with China if a policy of economic realignment was attempted. This was a fear equally shared by the US allies in Europe and the Arab world. The latter in fact feared that this shift would mean a reduction in capacities and in the American military commitments in the Middle East as the US defense resources were increasingly constrained ${ }^{16}$, eroding thus the US influence in a critical region.

On the other hand this change in approach and concept resulted in the departure of key figures in the Obama administration which had been in charge so far of monitoring and implementing US policies in the Asia-Pacific region. James B. Steinberg, Deputy Secretary of State, and Jeffrey Bader, director for East Asia at the National Security Council resigned and left.

\section{From Pivot to Rebalance: The Military Component}

In order to avoid criticism, the military component of the "pivot to Asia" was soon deemphasized, being the official discourse that American forces' presence in the region was not meant to contain China, as the US even welcomed the growing integration of China in the region. At the same time the "pivot to Asia" was rebranded as "rebalance". The crucial role of Asia, not only China, in the world economy was also stressed. Many observers were in any case not very much convinced with the new shades.

On 2 June 2012, the Secretary of Defense, Leon Panetta, chose the Shangri La Dialogue in Singapore to clarify the strategy; his remarks were given much attention: The US had always been a Pacific nation and America's fate was thus inexorably linked with the Asia-Pacific region; some of the world's fastest growing economies were in Asia and defense spending in the region was to surpass that of Europe in 2012.

The Secretary of Defense highlighted the goal of close cooperation with all to confront common challenges and to promote peace, prosperity, and security for all nations in the AsiaPacific region, emphasizing the crucial part that diplomacy, trade, and development played in the US engagement. As for defense policy, he said that it plays an essential role in promoting strong partnerships that strengthen the capabilities of the Pacific nations to defend and secure themselves.

He mentioned the necessity to rebalance towards the Asia-Pacific region with innovative rotational deployments, emphasizing the creation of new partnerships and new alliances as well as the strengthening of those alliances already existing with Japan, Korea, Australia while at the same time enhancing partnerships with Indonesia, Malaysia, India, Vietnam and New Zealand in support of shared security interests. But, at the same time, he underlined that this involvement in Asia was fully compatible with the development and growth of China: the U.S. involvement in the region, deepening the regional security

\footnotetext{
${ }^{16}$ Marlin, Mark E (coord): "Pivot to the Pacific? The Obama Administration's "Rebalancing" towards Asia", CRS, 28 March 2012, p.9, at http://www.fas.org/sgp/crs/natsec/R42448.pdf.
} 
architecture, should benefit the shared security and prosperity for the future of China and the US.

On military capabilities, he unveiled some crucial investments contained in the fiveyear budget plan: the retirement of older Navy ships and the replacement with more than 40 far more capable and technologically advanced ships; an increase in the number and the size of military exercises in the Pacific and port visits including the Indian Ocean; six aircraft carriers should be deployed in the region as well as the majority of cruisers, destroyers, Littoral Combat Ships, and submarines, reaching thus a ratio of $60 / 40$ between the Pacific and the Atlantic naval forces; investment in weapons systems to project military power such as an advanced fifth-generation fighter; an enhanced Virginia-class submarine; new electronic warfare and communications capabilities; improved precision weapons; new aerial-refuelling tankers; a new bomber model; advanced maritime patrol and anti-submarine warfare aircraft.

Leon Panetta also mentioned the development of new concepts of operations such as the Joint Operational Access Concept and Air-Sea Battle and said that, although these concepts and investments will take years to be fully accomplished, the United States military was rebalancing and bringing enhanced capability development to this vital region in a steady, deliberate and sustainable way ${ }^{17}$.

The impact of this speech was notorious, but there remained a crucial question to be solved, which were uncertainties about the resiliency of these changes after the presidential elections had taken place as important doubts existed on the sustainability and content of the new strategy.

\section{Rebalancing in the US Global Leadership Priorities}

After the reelection of Barack Obama on 6 November 2012 things started to change. In an effort of clarification, Thomas Donilon, US National Security Adviser, presented on the 15th of November the President Obama's Asia Policy before his first trip to the region. The speech made at the Center for Strategic and International Studies in Washington was rich in details.

First, he made clear which was the overarching objective of US policies in the region, namely to sustain a stable security environment and regional order rooted in economic openness, peaceful resolution to disputes, democratic governance and political freedom. The exceptional economic growth of Asia-Pacific required a stabilizing American presence. And one of the core elements of the US approach was a strategy of rebalancing. This strategy was meant as a long-term effort to better position the US for opportunities and challenges to be faced in the 21 st century and went far beyond just shifting military resources.

He mentioned the following set of objectives for achieving the strategy:

1- To Strengthen and modernize security alliances across the region.

2- To forging deeper partnerships with emerging powers.

\footnotetext{
17 "The US Rebalance Towards the Asia-Pacific: Leon Panetta", Shangri-La Dialogue, The IISS Asia Security Summit (2 June 2012), at http://www.iiss.org/en/events/shangri\%20la\%20dialogue/archive/sld12-43d9/firstplenary-session-2749/leon-panetta-d67b.
} 
3- To strengthen regional institutions and to engage more deeply in institutions, both global and regional, in order to promote regional cooperation, peaceful resolution of disputes and adherence to human rights and international law.

4- To pursue a stable and constructive relationship with China by ways of seeking a balance between elements of cooperation and competition.

5- To advance the region's economic architecture. In this regard, the TPP should deepen regional economic integration.

Regarding the sustainability of the military redeployment he stressed that the Obama administration should continue allocating enough resources to maintain a strong, flexible and broadly distributed regional presence. ${ }^{18}$

However, the appointment of John Kerry for Secretary of State and the departure of Leon Panetta from the Department of Defense reopened the debate and stoked fears regarding the real prospects of implementation.

John Kerry was ambivalent during his confirmations hearings and said frankly that he was not convinced that "increased military ramp-up in Asia was critical yet", adding: "that's something I'd want to look at very carefully". ${ }^{19}$ His first travel abroad was to Europe and the Middle East and in Berlin he said in reply to a question: "We are paying attention to Asia and so are you"... "but we're not doing it at the expense of Europe, not at all" months after his confirmation John Kerry traveled to Asia.

The obvious question was that the US could not pivot to Asia if possible crisis in the Middle East and the Gulf could turn into very complicated wars.

Obvious was also that in the new Obama administrations there were disagreements regarding the policies to be implemented. The White House wanted to hold the line ${ }^{21}$ and apparently the State Department was quite reluctant to provide full support to the new strategy. John Kerry in his remarks at the Tokyo Institute of Technology on 15 April 2013 while mentioning that President Obama made a smart and a strategic commitment to rebalance the interests and investments in Asia, he was not sharp and provocative enough. ${ }^{22}$ John Kerry did not want to further alienate a China which was carefully watching every movement by the US administration. Although the Democratic People's Republic of Korea nuclear and ballistic challenges justified the US rebalance, China on the contrary insisted that the American pivot to Asia had escalated tensions and would destabilize the region. In fact, on the 16th of April the Chinese government published a new White Paper on national defense

\footnotetext{
${ }^{18}$ Donilon, Thomas: "President Obama's Asia Policy and Upcoming Trip to the Region", Center for Strategic and International Studies (CSIS) (15 November 2012), at http://csis.org/files/attachments/121511_Donilon_Statesmens_Forum_TS.pdf.

19 La Franki, Howard: "US 'pivot to Asia': Is John Kerry retooling it?", CS Monitor, 20 February 2013, at http://www.csmonitor.com/USA/Foreign-Policy/2013/0220/US-pivot-to-Asia-Is-John-Kerry-retooling-it.

${ }^{20}$ Goodenough, Patrick: "In Europe, Kerry Says U.S. 'Pivot' to Asia Won't Come at Europe's Expense", CS News.com, 27 February 2013, at http://cnsnews.com/news/article/europe-kerry-says-us-pivot-asia-wont-comeeuropes-expense.

${ }^{21}$ Remarks by Tom Donilon, National Security Advisory to the President: "The United States and the AsiaPacific in 2013", The White House (11 March 2013), at http://www.whitehouse.gov/the-pressoffice/2013/03/11/remarks-tom-donilon-national-security-advisory-president-united-states-a.

${ }^{22}$ US Department of State: "John Kerry: Remarks on $21^{\text {st }}$ Century Pacific Partnership", 15 April 2013, at http://www.state.gov/secretary/remarks/2013/04/207487.htm.
} 
where this statement was included: "Some country has strengthened its Asia-Pacific military alliances, expanded its military presence in the region, and frequently makes the situation there tenser". 23

Nevertheless a week later, the US chairman of the Joint Chiefs of Staff, General Martin Dempsey, in a news conference at China's Ministry of National Defense in his response advocated the reorientation of the US policy ${ }^{24}$. The problem remained however, how to finance the military redeployment when spending cuts were already affecting operations in Asia. $^{25}$

All these changes and innovations have accelerated the process of change and adaptation in the Japan Alliance with the United States. The main question to solve in the next coming years is how far Japan can go if the new US strategy is maintained.

\section{The US-Japan Alliance Transformation after the Cold War}

\section{The Rapid Change of the Asia-Pacific Security Environment and the US Realignment}

After the Cold War, the US tried to reorganize its military presence in Asia Pacific. The George H. W. Bush Administration described the role of the US military forces in Northeast Asia as a "regional balancer, honest broker, and ultimate security guarantor". Later on, the Clinton Administration, after an evaluation of the possible threats, in particular the complex situation of the Korean peninsula, reconsidered the initially planned withdrawal of military forces. In April 1996, President Clinton in a speech to the Japanese Diet explained that the withdrawal of American forces from Japan and South Korea "could spark a costly arms race" in Northeast Asia ${ }^{26}$. In this context, both military alliances were redefined.

In the case of Japan, the Japan-US defense cooperation guidelines were modified in 1997. The new guidelines redefined and reinvigorated the Alliance, establishing a higher degree of coordination in time of peace and in the case of emergencies, going thus beyond the former contingencies contemplated during the Cold War: major international crisis or armed attacks against Japan. The principal revision of the guidelines authorized logistical support to the US in the case of military operations in "areas surrounding Japan that will have an important influence on Japan's peace and security" (the Korean Peninsula and Taiwan). However no authorization was granted to the Self Defense Forces of Japan to participate in combat missions along with the US military forces. The right of participation in collective defense was not mentioned and Japan thus did not fully expand its military role. Changes

\footnotetext{
23 "The Diversified Employment of China's Armed Forces", Information Office of the State Council, The People's Republic of China, Beijing (April 2013), at http://news.xinhuanet.com/english/china/2013-04/16/c 132312681.htm.

24 "In China, U.S. top military officer defends U.S. pivot to Asia", Reuters, 22 April 2013, at http://www.reuters.com/article/2013/04/22/us-china-usa-idUSBRE93L0LR20130422; Days later, in Yokota, General Dempsey said that "We'll continue to do whatever exercises we need to do to make sure we have the right command and control, the right skills, the right collaboration, interoperability with our allies in the region in the event that there is a miscalculation": "U.S. not backing down, Dempsey tells troops at Yokota", Japanese Online News, 26 April 2013, at http://japaneseonlinenews.com/2013/04/26/u-s-not-backing-down-dempsey-tellstroops-at-yokota/.

${ }^{25}$ Yuka, Hayashi: "Pentagon Cuts Feared Tripping Up Pivot to Asia", Wall Street Journal, 3 May 2013, at http://online.wsj.com/article/SB10001424127887324582004578456683694045890.html.

${ }^{26}$ Zhu, Zhiqun: "America's Military Presence in Northeast Asia after the Cold War: Winning Without Fighting?", Institute for East Asian Studies, vol. 12 no. 2 (Summer 2000), at http://www.ieas.or.kr/vol12_2/chiqunzuh.htm.
} 
were not very ambitious and the Alliance was still considered as regional but not global. At the same time the Clinton Administration tried to ameliorate its relationship with China developing a "strategic partnership" and thus trying to avoid any strong Chinese reaction and suspicions to the new guidelines.

Later on, the President George W. Bush Administration tried to give more prominence to Asia and the Pacific with a restructuration of the US global military deployment which implied upgrading and globalizing the US-Japan Alliance. Military cooperation was extended and deepened, focused particularly on the Air Force, the Navy and ballistic defense. ${ }^{27}$ The US government went as far as to openly urge Japan to revise the constitution and to include the right of collective defense. This went in line with the Japan government's interest in becoming a permanent member of the United Nations Security Council. In this endeavor Japan was supported by Condoleezza Rice. ${ }^{28}$ However one crucial constraint for becoming a permanent member responsible thus to deal with international peace and security was the article 9 of the Japanese constitution.

The regional context also encouraged changes. Political and security relations between Japan and China were constantly deteriorating. In December 2004 the National Defense Program Guideline, FY 2005 of Japan mentioned China as a challenge to national security because of its growing military modernization. ${ }^{29}$

Some months later, the US-Japan Security Consultative Committee made public a document entitled "US-Japan Alliance: Transformation and Realignment for the Future",30 that was qualified as "full of Cold War mentality" in China. ${ }^{31}$ A substantial list of technical military cooperation in bilateral security and defense along with essential steps to strengthen its international posture was included. But the subsequent internal political turmoil in Japan prevented any full implementation of the varied areas of operations considered, even less those new duties the Self Defense Forces of Japan would have to assume as well as initiatives proposed for the US realignment in Japan. ${ }^{32}$ The common strategic objectives for working together were also established in 2005 and 2007 by the US- Japan Security Consultative Committee. ${ }^{33}$ In both statements, the Democratic People's Republic of Korea and China were

\footnotetext{
${ }^{27}$ See in this regard: Niksch, Larry A.: "U.S. Security Policies in the Western Pacific", Presented at the 2005 Pacific Symposium sponsored by the National Defense University, the U.S. Pacific Command, and the Asia Pacific Center for Security Studies p.7-8, at http://www.dtic.mil/cgi-bin/GetTRDoc?Location=U2\&doc=GetTRDoc.pdf\&AD=ADA441176; Medeiros, Evan S.: "Strategic Hedging and the Future of Asia-Pacific Stability", The Washington Quarterly, vol. 29, no. 1 (Winter 2005-2006), p.150, at http://www.cerium.ca/IMG/pdf/Strategic Hedging and the Future of AsiaPacific_Stability.pdf.

28 Secretary Condoleezza Rice: "Remarks at Sophia University", 19 March 2005, at http://20012009.state.gov/secretary/rm/2005/43655.htm.

${ }^{29}$ The Guideline stated: "China, which has a major impact on regional security, continues to modernize its nuclear forces and missile capabilities as well as its naval and air forces. China is also expanding its area of operation at sea. We will have to remain attentive to its future actions": Wu, Xinbo: "The End of the Silver Lining: a Chinese View of the US-Japanese Alliance", The Washington Quarterly, vol. 29, no. 1 (Winter 20052006), p.123, at http://www.brookings.edu/ /media/research/files/articles/2006/12/winter\%20china\%20xinbo/xinbo20060101.pd $\underline{f}$.

${ }^{\overline{3} 0}$ Security Consultative Committee: "U.S.-Japan Alliance: Transformation and Realignment for the Future", 29 October 2005, at http://www.mofa.go.jp/region/n-america/us/security/scc/doc0510.html.

${ }^{31}$ Xiang, Xinfeng: "US-Japan Military Alliance Cold War Mentality", People's Daily, 5 November 2005.

${ }^{32}$ Klingner, Bruce: "How to Save the US-Japan Alliance", The Heritage Foundation, Backgrounder, no. 2308 (26 August 2009), p. 3.

${ }^{33}$ US-Japan Security Consultative Committee: "Joint Statement", 19 February 2005, at

http://www.mofa.go.jp/region/n-america/us/security/scc/joint0502.html;
} 
mentioned. In the case of China, the question of transparency of its military affairs and consistency between his stated policies and actions was underlined.

\section{The Alliance during the Governments of the Democratic Party of Japan}

Years later the strategic vision of Japan was again redefined under the new government of the Democratic Party of Japan (DPJ) which rose to power in 2009. If the US-Japan alliance was not in the "DPJ's DNA" ${ }^{34}$ and the Prime Minister Yukio Hatoyama created significant problems to the US-Japan Alliance ${ }^{35}$, China's military and economic expansion still frighten Japan as well as the dangers implicit in any possible US-China rapprochement, as occurred in 1972, if the management of the US- Japan bilateral Alliance happen to deteriorate. Adding to this, the sustained Japanese economic decline and increasingly weak official approaches on military security were a matter of concern in the United States ${ }^{36}$. On 17 December of 2010 the cabinet of the Prime Minister, Naoto Kan, approved the National Defense Program Guidelines for FY 2011 and the Mid-Term Defense Program (FY2011-FY2015). The guidelines had introduced several important changes, taking in consideration "the global shift in the balance of power with the rise of powers such as China, India and Russia". Japan would participate more actively to improve the international security environment, including United Nations peacekeeping operations and activities to deal with non-traditional security issues and in international nuclear disarmament, considering the US nuclear deterrent a vital element until a nuclear zero is not achieved. A large-scale landing invasion against Japan was considered unlikely to occur and the emphasis was put on the southwest of Japan where a security and defense vacuum had to be filled. Japan had to place more importance on a "dynamic deterrence which takes into account an operational use of the defense forces" and "will develop a dynamic defense force that possesses readiness, mobility, flexibility, sustainability and versatility". The guidelines mentioned some priority areas ${ }^{37}$ and the necessity to enhance the bilateral cooperation with the US, strengthening the joint training and joint/shared use of facilities and further development of equipment and technology cooperation. According to these guidelines, Japan had to play an active role in solving regional and global issues ${ }^{38}$.

The restructuring and re-location of the Japanese armed forces was quite ambitious and challenging, given its cost. The Air Force, the Navy and antisubmarine warfare, ballistic

Joint Statement of the Security Consultative Committee: "Alliance Transformation: Advancing United StatesJapan Security and Defense Cooperation" (1 May 2007), at http://www.mofa.go.jp/region/n-america/us/security/scc/joint0705.html.

${ }^{34}$ Glosserman, Brad: “Breaking point for the alliance?”, Pacific Forum CSIS, PacNet, no. 19 (12 April 2010).

35 Yukio Hatoyama became Prime Minister in 2009. During the electoral campaign he promised to the Okinawans that he would oppose the relocation of the Futenma Marine Corps Air Station in a less congested part of the island, as was agreed in 2006. Later, the DPJ governments, trying to appease the Okinawans, were unable to solve the problem, creating local expectations that were impossible to meet, thus escalating the sense of grievance in the island and casting an increasing shadow over the bilateral Alliance.

${ }^{36}$ Sunohara, Tusuyoshi: "The Anatomy of Japan's Shifting Security Orientation”, The Washington Quarterly, vol. 33, no. 4 (October 2000), p.53.

${ }^{37}$ In particular: Ensuring security of sea and air space surrounding Japan; Response to attacks on offshore islands; Response to cyber attacks; Response to attacks by guerrillas and special operation forces; Response to ballistic missile attacks; Response to complex contingencies; Response to large-scale and/or chemical, biological, radiological and nuclear disasters.

${ }^{38}$ Yamaguchi, Noboru: "Deciphering the New National Defense Program Guidelines of Japan", The Tokyo Foundation, Policy Research Brief, 2011 at

http://www.tokyofoundation.org/en/additional_info/PRB_N.Ymgc.pdf; Defense Minister's Statement on the Approval of the 'National Defense Program Guidelines for FY2011 and beyond' and the 'Mid-Term Defense Program (FY2011-FY2015)', 17 December 2010, at http://www.mod.go.jp/j/approach/agenda/guideline/2011/daijin_e.pdf. 
defense and ISR capabilities received special attention. ${ }^{39}$ All these changes implied an accommodation to the US strategies for the region. As it could have been expected, China was very critical: "the alliance should not go beyond the bilateral scope and undermine the interests of a third party".

But Japan and even the US had a good argument for some of the changes that were promoted in the new guidelines and the defense program: The unstable nuclear Democratic People's Republic of Korea and its ballistic capabilities. At this time, a possible growth of Russian military strength in the region was not taken into consideration, despite the Kuril Islands perennial issue. Northeast Asia had a low profile in the Russian foreign and security policy. ${ }^{40}$ However the Russian debut in the East Asian Summits took place in 2010 and a reorganization and build-up of military forces in the Kuril Islands was decided.

The main problem lay in the real possibilities for implementation of the new guidelines and the defense program and the remaining constrains emanating from the constitution of Japan. The impact of the nuclear disaster of March 2011 on the Japanese economy was colossal, affecting the tempo for the procurement of the new platforms and systems, which added to the fact that the Japanese military budget would not substantially grow. In addition to this, a more active role in US-led military operations out of Japan needed some more time and efforts than the government was willing to make. On the positive side, the US participation in Operation Tomodachi, where a total of 130 aircraft, 12,510 personnel and over 16 American naval ships took part, supporting Japan in disaster relief, was highly appreciated by the Japanese government and the Japanese people, even if it increased fears from the US side that this tremendous disaster would imply a "more inward-looking focus on humanitarian assistance and disaster relief operations" by the government and the Japanese Self Defense Forces ${ }^{41}$.

On the other hand, the thorny issue of the Marine Corps Air Station in Futenma relocation was not solved, distracting both countries from the principal strategic objectives and providing some ammunition in the United States for new proposals in the direction of a rethink of the US strategy and force structure in the Pacific. ${ }^{42}$

Nevertheless in June 2011, the joint Consultative Committee updated the common Strategic Objectives, taking into consideration the assessment of the changing security environment. China, Russia, India and ASEAN were mentioned. In the case of China, questions linked to the openness and transparency of its military modernization and its activities as well as confidence building measures were again underlined. the following areas were emphasized in the field of mutual cooperation: Strengthening deterrence and contingency response; Alliance cooperation in a regional and global setting; enhancing

\footnotetext{
${ }^{39}$ Fouse, David; "Japan's 2010 National Defense Program Guidelines: Coping with the 'Grey Zones", AsiaPacific Center for Security Studies (April 2011), at http://www.apcss.org/wp-content/uploads/2011/12/FouseJapan-Final.pdf.

${ }^{40}$ Amirov, Viacheslav B.: "Russia's Posture in and Policy towards Northeast Asia", in

Blank, Stephen J. (ed.): "Russia's Prospects in Asia", Strategic Studies Institute, SSI Monograph (December 2010), pp 1-6.

${ }^{41}$ Fouse, David: "Japan unlikely to Redirect Defense Policy", Pacific Forum CSIS, PacNet, no. 26 (5 May 2011), at http://csis.org/publication/pacnet-26-japan-unlikely-redirect-defense-policy.

${ }^{42}$ Ennis, Peter: "Pressure builds for US shift on Okinawa", Pacific Forum CSIS, PacNet, no. 29 (19 May 2011), at

http://csis.org/publication/pacnet-29-arabia-and-china-planning-worst-pressure-builds-us-shift-okinawa;

Senators Carl Levin, John McCain, and Jim Webb criticized the realignment plan as "unrealistic, unworkable, and unaffordable" and the Congress finally established strict limits for funding the planned realignment.
} 
Alliance foundations; improving information security; bilateral frameworks for more effective operational cooperation and closer cooperation in equipment and technology ${ }^{43}$. Space, cyberspace, ballistic missile defense, information security, bilateral planning, non-combatant evacuation operations, joint training and exercises in both countries and trilateral cooperation were also mentioned. All this was again emphasized in the meeting of the defense ministers that took place in October 2011. The Minister of Defense of Japan, Yasuo Ichikawa, in the press conference said that "we have come to be united to further promote this dynamic JapanU.S. defense cooperation". ${ }^{4}$

Thus, once the Obama administration launched the "pivot to Asia" and "the rebalance to Asia-Pacific" and once the new Strategic Guidance of the Department of Defense was published, the US- Japan alliance was sufficiently prepared to move in this new direction. Although the DPJ had demonstrated its inability to effectively handle national security issues in a period of rapid change as a consequence of its unrealistic pacifism and that despite the efforts of the Prime Minister Yoshihiko Noda ${ }^{45}$, the concept of dynamic defense adopted by Japan fit well into the new operational concepts of the US. ${ }^{46}$ Jointness and interoperability across the services in Japan and the US was enhanced in the Armitage-Nye report, as well as closer defense industry collaboration, exports and imports of defense hardware and joint developments $^{47}$. In fact, in 2003 the Japanese government had already allowed providing weapons technology to the US and in 2004 the joint development of a missile defense system had been approved. These exceptions in the arms exports control policy were institutionalized in December 2011, when the Japanese government lifted the ban on exports of components for the F-35 fighters ${ }^{48}$.

In this new context, after almost a decade of problems and discussions on relocations, transfer of Marines and return of land, the thorny issue regarding the US realignment in Japan had to be solved quickly and decisively. In this regard, the Security Consultative Committee in its meeting in April 2012 focused on the kind of problems affecting the Alliance. ${ }^{49}$ The Joint Statement was a step forward, but serious challenges still remained in the way for a final solution, in particular budget cuts, new tensions arising on burden sharing and the still lingering strong opposition of the people living in Okinawa.

\footnotetext{
43 "Joint Statement of the US-Japan Security Consultative Committee", 21 June 2011, at http://www.state.gov/r/pa/prs/ps/2011/06/166597.htm.

44 “Japan-U.S. Defense Ministers' Joint Press Conference”, 25 October 2011, at http://www.mod.go.jp/e/pressconf/2011/10/111025_japan_us.html.

45 "Japan under DPJ rule", Harvard International Review, 31 January 2013, at http://hir.harvard.edu/mobilemight/japan-under-dpj-rule?page=0,1.

${ }^{46}$ See in this regard Arrmitage Richard L. and Nye Joseph S.: "The US-Japan Alliance. Anchoring Stability in Asia”, CSIS, August 2012, p.11, at http://csis.org/files/publication/120810_Armitage_USJapanAlliance Web.pdf.

${ }^{47}$ Ibid., pp.12-13.

${ }^{48}$ See in this regard: "Abe administration changes basic concept in approving export of weapons parts", The Asahi Shimbun, 2 March 2013, at http://ajw.asahi.com/article/behind_news/politics/AJ201303020050; Yoshida Reiji: "Japan to join F-35 parts output, export strategy", The Japan Times, 2 March 2013, at http://www.japantimes.co.jp/news/2013/03/02/national/japan-to-join-f-35-parts-output-exportstrategy/\#.UaaQRdieTcs.

49"Joint Statement of the Security Consultation Committee", 26 April 2012, at http://www.state.gov/r/pa/prs/ps/2012/04/188586.htm; On 8 February 2012, the two governments released a Joint Defense Posture statement in which it was said that they had agreed to delink two aspects of the planned relocation of US forces in Japan, the relocation of Marines within Okinawa and moving some of the forces to Guam from the relocation of Marine Corps Air Station Futenma at Henoko-saki area.
} 
Nevertheless, the strategic dialogue remained underdeveloped ${ }^{50}$ and Japanese politics remained unpredictable. In this annoying political environment, Noburu Yagamuchi from the National Defense Academy of Japan, noticed that Japan had "to work hard to foster the preconditions for a US emphasis on Asia's security...peace and stability in the Asia Pacific region calls for Japan to pay keen attention to out of area security problems and thus secure the US's political commitment to the region". 51

In order to ameliorate the bilateral relationship and to decisively move forward, Prime Minister Noda met President Obama in the White House on the 30th April 2012. Both leaders reaffirmed the Alliance and pushed the agenda for deepening the bilateral trade and investment, which was an important part of the US design for the rebalance to Asia Pacific. But Japan had to resolve its internal political debate on whether to enter the Trans-Pacific Partnership Agreement (TPP) negotiations and as the general elections were very close, few were the significant measures the Japanese government could adopt at the current stage. It is important however to note that in August 2012 Japan published the annual defense White Paper, clearly linking the implementation of the dynamic defense concept with the US and Japan defense cooperation. ${ }^{52}$

\section{The new Shinzo Abe Government}

As it was already anticipated, given the deterioration of the DPJ party, on 26 December 2012 Shinzo Abe became Prime Minister following the LDP's landslide victory in the general elections of 16 December. On the same day, the Primer Minister instructed the Defense Minister Itsunori Onodera to review the National Defense Program Guidelines for FY 2011, the Mid-Term Defense Program (FY2011-FY2015) and the US-Japan defense cooperation guidelines of 1997 to study how to respond to the Chinese military buildup and to its maritime expansion. It was expected that the Prime Minister would use the revision to reconsider the right of collective self defense, not allowed under the traditional interpretation of the constitution, but, as mentioned, considered to be a fundamental pillar for strengthening the US-Japan Alliance, as well as to support activities to troops of third countries through the use of force.

The process of revision was quite rapid. On the 17th of January, the US and Japan initited a revision of the defense cooperation guidelines at a working level meeting, in order to facilitate cooperation between the Armed Forces and in order to explore the different roles, missions and all military capabilities considered necessary to meet the regional security challenges. On the 25th of January the cabinet decided to review the National Defense Program Guidelines and Mid-Term Defense Program and four days later approved the increase in the defense spending, reaching 52.5 billion US dollars, the first modest increase $(0.8 \%)$ in eleven years. On the 12th of February the Democratic People's Republic of Korea conducted its third nuclear test and the Minister Itsunori Onodera defended that Japan had the right to develop its ability to preemptively strike against an imminent attack.

\footnotetext{
${ }^{50}$ See Tatsumini, Yuki: "The US and Japan Make a Good Step Forward, for Now", Pacific Forum CSIS, PacNet, no. 29 (3 May 2012); McDevitt, Michael: "The Evolving Maritime Security Environment in East Asia: Implications for the US-Japan Alliance", Pacific Forum CSIS, PacNet, no. 33 (31 May 2012); Smith, Sheila A.: "A Strategy for the US-Japan Alliance. Policy Innovation Memorandum", Council on Foreign Relations (April 2012), at http://www.cfr.org/japan/strategy-us-japan-alliance/p28010.

${ }^{51}$ Yamaguchi, Noburu:'US Asian pivot calls for Japanese strategic response", East Asia Forum, 4 May 2012, at http://www.eastasiaforum.org/2012/05/04/us-asian-pivot-calls-for-japanese-strategic-response/.

${ }^{52}$ Ministry of Defense of Japan: “Defense of Japan 2012”, at http://www.mod.go.jp/e/publ/w_paper/2012.html.
} 
A study panel was formed to study the creation of a national security council to solve the lack of coordination among ministries and a study group of experts examined the cases for exercising collective self-defense. ${ }^{53}$

And on the 22nd of February, President Barack Obama and Prime Minister Shinzo Abe held a meeting in the White House. Both leaders shared their views on security, how to strengthen the Alliance, the revision of the guidelines, the realignment, the final relocation of the Marine Corps Air Station without further delay, the security environment in Asia Pacific and closer cooperation with third countries, the situation in the Middle East and North Africa, global issues such as climate change, energy and the global state of the economy and an extended discussion on TPP, a key initiative to integrate the economies of Asia Pacific, excluding China ${ }^{54}$.

In a speech at the Center for Strategic and International Studies, Shinzo Abe told the audience: "I am back and so is Japan". 55

But the process of Japan normalization called for managing important challenges and entailed significant complications in the economic and military domains.

In the military domain, Japan, given the new strategic situation, had to continue adopting new critical policies and to take practical steps to put on the table new assets needed in order to become a predictable and reliable ally for the United States. This was the only way for Japan to become as strong and solid an ally as the United Kingdom. Otherwise, the relevance of Japan would decrease for the United States as other Asian states start acquiring greater relevance.

In the economic domain, the new Japanese government has committed Japan to join the TPP but TPP negotiations ahead will be tough and will probably require the final parnership to be watered down in order to make it acceptable, given the complex interests to be considered and the slow process of negotiations.

The main question to be answered in the next coming years is how can Japan manage a changing security environment, adopting at the same time strong cooperative initiatives with China and not provoking it while approving new doctrines and operational concepts, acquiring new military assets and suppressing the constitutional constrains that limit the collective self-defense.

\footnotetext{
${ }^{53}$ Green, Michael J. and Szechenyi, Nicholas: "US-Japan Relations”, in Baker, Carl and Glosserman, Brad (eds.) Comparative Connections, vol. 15, no. 1 (January - April 2013).

${ }^{54}$ "Remarks by President Obama and Prime Minister Abe of Japan After Bilateral Meeting", The White House, 22 February 2013, at http://www.whitehouse.gov/the-press-office/2013/02/22/remarks-president-obama-andprime-minister-abe-japan-after-bilateral-mee.

55 “Statesmen's Forum: Shinzo Abe, Prime Minister of Japan”, Center for Strategic and International Studies (22 February 2013), at http://csis.org/files/attachments/132202_PM_Abe TS.pdf.
} 


\section{Rethinking Possible Future Scenarios}

Several scenarios have been presented for the year $2030^{56}$. Let me say first that some of them are not very convincing, as they simplify too much and focus only on the possible actions and reactions of China, Japan and the United States. We have to take into account the following factors: the role of nuclear weapons in the region which will endure because of the limited steps taken for global and regional denuclearization, the soft (and suicidal could we add) approaches of China regarding the nuclear activities of the Democratic People's Republic of Korea, the extreme weakness of NPT, and the significant modernization and expansion of nuclear arsenals ${ }^{57}$ versus the NPT obligations; Russia's growing military reorganization in the Pacific $^{58}$; the impact in the region of the increasing global role of China; the process of rapid change in the balance of power that is taking place versus a go slow policy of adaptation in Japan determined by the political-economic constrains; the extreme weakness of Asian institutions for dealing with hard security issues; and the uncertainties linked to the economic growth of the different states. These factors are not sufficiently integrated in the different analysis.

The NIC report," Global trends 2030", presents four scenarios:

1. A continuation of the present order and US leadership. Continued US maritime preeminence and the preponderance of power enjoyed by the United States and its allies deter aggressive actions by Beijing or Pyongyang. Economic integration continues to be oriented around a Pacific rather than an exclusively Asian axis.

2. A balance of power order of unconstrained great power competition fueled by dynamic shifts in relative power and a reduced US role. Some Asian powers might develop and seek to acquire nuclear weapons as the only means of compensating for less US security.

3. A consolidated regional order in which an East Asian community develops along the lines of Europe's democratic peace, with China's political liberalization a precondition for such a regional evolution.

4. A Sinocentric order centered on Beijing that sustains a different kind of East Asian community on the basis of China's extension of a sphere of influence across the region. The biggest uncertainty in this scenario is the sustainability of the economic model of China and its consequences.

In my opinion the most likely scenario is n.2.

\footnotetext{
${ }^{56}$ Jimbo, Kem: "Dynamics of Power shift from US to China-Asia-Pacific Security and Japan's Foreign Policy", Japan Foreign Policy Forum, nos. 13-15, Special Extensive Edition (March-April 2013), at http://www.japanpolicyforum.jp/en/archive/no13/000445.html; More recently Swaine, Michel D. and al.: China's Military and the US-Japan Alliance in 2030, Carnegie Endowment for International Peace, 2013, at http://carnegieendowment.org/files/net_assessment_full.pdf; "Global Trends 2030. Alternative Worlds", National Intelligence Council (NIC) (December 2012), at http://globaltrends2030.files.wordpress.com/2012/12/global-trends-2030-november2012.pdf.

${ }^{57}$ China's nuclear developments are problematic at global and regional level.

58 "The Defense of Japan 2012", op. cit, presents the deep military reorganization of Russia, the modernization of the Armed Forces, including the nuclear forces, and the deployments and operations in the vicinity of Japan.
} 
A recent report by Carnegie Endowment for International Peace presents six alternative security scenarios in 2030 that I summarized as follows:

1. Eroding Balance: China will make notable absolute gains in several critical military capabilities. In this scenario the regional security environment would be more unstable than at present, although it would still be manageable.

2. Limited Conflict: China will increase his relative military capabilities vis à vis Japan and the US- Japan Alliance. In this unstable scenario of increasing competition and rivalry, the probability of serious crisis or limited conflict would likely increase.

3. Mitigated Threat: High levels of cooperative engagement between China and Japan and China and the US- Japan Alliance and a decreased capacity for serious tensions and crisis could exist. In this not likely scenario cooperation would be reinforced by deepening levels of economic interdependence between China and Japan.

4. Asian Cold War: The strategic rivalry and competition in the political, economic and military domains increases the likelihood of severe political-military crisis in the absence of credible mutual security assurances. In this less likely scenario, Japan would become close to a normal conventional military power and a fully active security partner of the US.

5. Sino-Centric Asia: As the result of a major withdrawal of US forces in the Western Pacific. In this scenario, considered highly unlikely but not entirely inconceivable, Japan will accommodate to an economically pre-eminent but politically and militarily non-threatening China.

6. Sino-Japanese Rivalry: As the consequence of the US withdrawal or hollowing out in the Western Pacific. In this scenario, Japan will try to achieve an independent military power, including nuclear weapons.

In my opinion 1, 2, 4 and 6 scenarios are likely.

On the other hand, Tokyo Foundation presents four scenarios ${ }^{59}$ where the US-China relations are the key variable in the Asian regional order:

1 A hierarchical liberal order in which cooperation between the United States and China is sustained under the US superior power diffusion.

2 An asymmetric balance of power of sustained US superior power-diffusion that implies deeper conflicts between the United States and China.

3 A great power order in which cooperation between the United States and China is sustained with the power diffusion of the two states heading toward equilibrium.

4 A Cold War type bipolar order of deeper conflicts between the United States and China as the power diffusion of the two states reaches an equilibrium ${ }^{60}$.

\footnotetext{
${ }^{59}$ In these scenarios there are many uncertainties on the China continuous rise as well as the pathway of the US and Western economic decline.

${ }^{60}$ Jimbo, Ibid.
} 
According to the scenarios presented by NIC and Tokyo Foundation, professor Ken Jimbo considers that Japan must be prepared for scenarios 2, 3 and 4, while trying to maintain the first scenario of hierarchical liberal order as long as possible. I share this opinion with some nuances. Taking into consideration the difficulties presented in the transformation of the Japanese military in the period covered by this article, 1997-2012, where the balance of power in the region was transformed, I think that a scenario of increasing erosion in the regional balance of power due to economic reasons is the most likely. ${ }^{61}$ Several factors work towards this direction: cuts in the Western military budgets and political constraints, different actors that try to modify the present US military predominance in several regions, the global engagement of the US, and the global economic reorganization and competition by emerging economies. In this scenario, China and Russia will try to favor the military decline of the US. Japan, given the modernization of the nuclear arsenals, the proliferation and expansion of WMD in the region and beyond, the untenable NPT and the erosion of the conventional balance of power, will try to develop and deploy nuclear weapons and reinforce missile defense. Some specialists will dismiss this assessment considering that the possibility of a military independent Japan is not realistic. I do not share this opinion. The US requirements for the Japanese military transformation are a hard task. The new doctrine of Air-Sea Battle and its application to East Asia requires as a precondition for its implementation too many and rapid political and economic changes that Japan is probably not in a condition to deliver in this decade and beyond: Rapid revision of the constitution; substantial increase of the military budget; greater joint planning, training and operations with the US; additional C4ISR capabilities and its defense; doctrinal and technical integration of Forces and assets plus increasing integration of his Armed Forces with the Armed Forces of the US; advanced naval capabilities; increase and modernization of the obsolete Japanese air forces; development of operational aerospace strategies; and closing the window of vulnerability of the Japanese bases in the case of a first strike ${ }^{62}$.

Let me finish this article emphasizing that all these changes and likely scenarios have critical consequences for the Atlantic Alliance. The approaches of a substantial number of European NATO countries are still very parochial and, in some sense, pretty blind ${ }^{63}$.

\section{Conclusions}

The Japan-US Alliance needs an important and profound adaptation to the new situation in Asia-Pacific. In the last few years, the United States, after some hesitation and some modifications, has proposed a strategy to rebalance the increasing military imbalance in AsiaPacific created de facto by China, although it is not the only goal in the new strategy proposed. Looking at the present official statements and requests for clarification from both, the United States and China, the reality is that China can't be considered a status quo power as was intended at the beginning of this century and some of us defended. Its military and

\footnotetext{
${ }^{61}$ I consider that it is quite reasonable to maintain the increasing economic and military rise of China at least in this decade.

${ }^{62}$ See Swaine, Michel D. et al.: “China's Military and the US-Japan Alliance in 2030”, pp 127-148, Carnegie Endowment for International Peace, at http://carnegieendowment.org/files/net_assessment_full.pdf.

${ }^{63}$ See for instance the recent report by IAI, Real Instituto Elcano, PISM, UI: "Towards a European Global Strategy. Securing European Influence in a Changing World” (28 May 2013), at http://www.iai.it/pdf/egs_report.pdf.

In general, the EU defense approaches made in Brussels in the last decade are very questionable. The most interesting thing, looking at the present mess, is that nobody takes responsibility for this lack of vision, the very inappropriate nominations (corruption), Kantian approaches and the dilapidation of the taxpayer money, experimenting and playing with the EU defense. All this, saying something soft, has led to the present impasse.
} 
economic growth in comparative terms, its pushy activities and the different estimates and scenarios for the next coming years do not allow keeping this thesis any longer. We have to call things by name, ignoring word games that are a mere flatus vocis. On the other hand the pivot to Asia strategy or the rebalance are more confrontational than cooperative strategies and forget the possible Russia's role in the region.

This "sea change" breaks the security design hitherto maintained in Asia - Pacific and means a remarkable challenge for China's neighbors and in particular for the US-Japan Alliance and its reconfiguration. At the same time we can't put aside the challenges posed by this transformation to China itself. Confidence building and deeper dialogues among different actors are needed.

The problem that appears on the Japanese military horizon is the great difficulty in adaptation to the new security environment adopting in a relatively short period of time all the concepts and strategies that US will seek to develop in the region, in order to avoid a greater military imbalance. At the same time, the fears regarding possible cuts in the US military spending, a possible temptation in the US to restructure its relations with China at the expense of its neighbors or else, the accommodation of Asian countries to the interests and designs of China are still there and are viewed with concern by different countries.

All this will entail important consequences in the go slow course adopted by Japan in its military adaptation since the end of the Cold War and its possible deep military transformation.

This impasse in the Asia-Pacific is also a great lesson to be learned by the EU security and defense alchemists in Brussels headquarters. But don't worry. Disneyworld is more fun. Nobody assumes responsibilities. 